\title{
Towards Sustainable Integrated Watershed Ecosystem Management: A Case Study in Dingxi on the Loess Plateau, China
}

\author{
Liding Chen $\cdot$ Lei Yang $\cdot$ Wei Wei $\cdot$ \\ Ziting Wang $\cdot$ Baoru Mo $\cdot$ Guojun Cai
}

Received: 30 December 2010/Accepted: 17 December 2011/Published online: 19 January 2012

(C) Springer Science+Business Media, LLC 2012

\begin{abstract}
The Chinese government initiated a massive conservation program called "Grain-for-Green" in 1999 to reduce soil erosion and improve ecosystem function. Implementing practical sustainable development in the loess plateau still remains problematic, particularly in its eco-fragile areas. Here we discussed an approach for sustainable development at the watershed scale by integrating land use suitability, ecosystem services and public participation in the loess hilly area. We linked land use scenario analysis and economic modeling to compare the outcomes of three scenarios, CLU (Current Land Use), GOLU (Grain-production Oriented Land Use) and PSLU (Potential Sustainable Land Use). The results indicated that compared to PSLU, GOLU may provide a higher economic productivity in the short-term, but not in the long-term. CLU ranked lowest in terms of economic benefits and did not meet the daily needs of the local farmers. To reconcile the land use adjustments with farmers' basic needs, a laborsaving land use strategy is necessary. Since the PSLU scenario assumes that slope cropland should be converted to pastures or orchards, more time may be available for offfarm work and for more public participation in integrated ecosystem management. Financial support to the local farmers for environmental conservation should be modulated in function of their positive contribution to ecosystem management.
\end{abstract}

L. Chen $(\bowtie) \cdot$ L. Yang $\cdot$ W. Wei

Research Center for Eco-Environmental Sciences, CAS-State

Key Lab of Urban and Regional Ecology, Shuangqing Road 18, Haidian Beijing, Beijing 100085, China

e-mail: liding@rcees.ac.cn

Z. Wang $\cdot$ B. Mo $\cdot$ G. Cai

Gansu Academy of Forestry Sciences, Lanzhou, Gansu, China
Keywords Sustainability - Land use suitability evaluation · Ecosystem service $\cdot$ Public participation . Integrated ecosystem management $\cdot$ The loess plateau

\section{Introduction}

Ecosystem management addresses trans-boundary, interdisciplinary, and multi-party issues from an ecosystem perspective (Chuenpagdee and others 2006; Yaffee 1997; Berry and others 1998; Pavlikakis and Tsihrintzis 2000). Successful implementation of ecosystem management depends largely on stakeholders' acceptance and participation (Cervantes and others 2008; Chuenpagdee and others 2006; Prager and Freese 2009). The specific issue that challenges ecosystem management varies greatly globally, therefore no single formula, or institutional arrangement, is applicable to all situations (Ostrom 2007). Ecosystem management seeks to sustain multiple ecosystem services but often uses, as a reference point, historic conditions that are not achievable in a rapidly changing world (Chapin and others 2009; Christensen and others 1996). Since both ecosystems and human activities vary tremendously in heterogeneous environments, ecosystem management should be implemented adaptively (Chapin and others 2009). In the past decade, adaptive ecosystem management emerged as a new research area in ecosystem science and management, which shifts from the previous focus on static structures (stands, patches) to adaptive dynamic processes (Heinimann 2010). In addition, both ecosystem services and human needs are addressed, and ecosystem services become the cornerstone for meeting human needs and sustainable development. In ecosystem service assessments, ecologists focus on the ecosystem and organism characteristics that deliver services (Kremen 
2005; Balvanera and others 2006) while economists prefer to exploring various techniques to determine the value of services to humanity (Knoche and Lupi, 2007; Swintona and others 2007; Tong and others 2007; Ingrahama and Foster 2008; Li and others 2008). Despite the booming interest in ecosystem services, up to now no standard methods exist to interpret and insert services in conservation assessments (Turner and Daily 2008).

This study addresses the ecosystem services related to soil and water conservation. These services are expected to lead to economic benefits by reducing soil erosion thereby preventing further decline in crop yield. With an increase in human activity and arable land losses, land use management agents often deliberately choose low-diversity options, such as single-species production forests or an economy largely based on a single industry, because these can be managed efficiently (Chapin and others 2009). Achieving a sustainable land use pattern by integrating ecosystem services in ecosystem management is especially important in fragile ecosystem.

Integrating environmental conservation with social and economic development is the objective of sustainable development. Transformation to a potentially more beneficial ecosystem state is the explicit goal of sustainable development programs in developing nations (Loorbach 2007). Assessing these issues must be based on a specific space scale, such as a watershed. Since the flow of services in ecosystems requires that they function as a whole system, the structure, composition and diversity of the ecosystem in a watershed are important components of the natural capital that gives service value. Therefore, integrated watershed ecosystem management becomes a foundation unit in sustainable development (German and others 2006).

As one of the most serious soil erosion areas in the world, the loess plateau has received a lot of attention in China and globally. Since 1980s, the idea of integrated watershed ecosystem management has been recommended and some technical measures are proposed (Chen and others 2007a; McVicar and others 2007a, 2010). In 1999, the afforestation project "Grain-for-Green" was initiated in China for soil erosion control and ecosystem improvement by converting the slope cropland into lands with ecosystem services. In this project, it is important to motivate local farmer to participate in the ecosystem management. In this study, we built an ecological-economic model to investigate whether a potential sustainable land use pattern in a watershed of the loess hilly area is economically viable. Part of this model is to determine the potential trade-off between soil and water conservation and economic earning.

The specific objectives of this study are to (1) evaluate watershed-scale land use suitability evaluation from the ecosystem health perspective; (2) compare the value of ecosystem services and economic benefits between different land use scenarios; and (3) propose an integrated watershed management scheme for sustainable development in the semi-arid loess hilly area.

\section{Study Area and Methodology}

\section{Study Area}

The study area is located in Longtan watershed in Dingxi of Gansu Province, China $\left(35^{\circ} 43^{\prime}-35^{\circ} 46^{\prime} \mathrm{N}\right.$ and $104^{\circ} 27^{\prime}-$ $104^{\circ} 31^{\prime} \mathrm{E}$ ), covering $16.14 \mathrm{~km}^{2}$ with an average elevation of $1900 \mathrm{~m}$ a.s.l.. The watershed belongs to a typical semiarid loess hilly area and is characterized by a highly fragmented landscape. The annual mean (1961-2006) temperature is about $6.8^{\circ} \mathrm{C}$ and annual mean rainfall is about $386 \mathrm{~mm}$ with most rainfall occurring as high intensity rainstorms in summer (e.g., July to September). The annual mean potential evaporation (pan evaporation) is about $1649 \mathrm{~mm}$. Soils are mainly composed of loess soil with low organic matter, low fertility, and partially sierozem. The predominant land use types are rain-fed cropland and sparse natural grassland, and then pasture grassland, shrubland, woodland, residential land and fallow cropland (Table 1). The natural vegetation includes Stipa bungeana, Leymus secalinus, Heteropappus attaicus. The vegetation planted by human includes Medicago sativa, Caragana korshinskii, Armeniaca sibirica, Platycladus orientalis, Pinus tabuliformis. As the climate is semi-arid, water shortage is the major constraint to vegetation growth and agricultural production, and therefore sustainable development. There are about 401 households with 1,545 people resided in the watershed in 2009.

Table 1 Current land use in the study area (2009)

\begin{tabular}{llrl}
\hline Land use type & & $\begin{array}{l}\text { Area } \\
\text { (ha) }\end{array}$ & $\begin{array}{l}\text { Area } \\
\text { percentage } \\
(\%)\end{array}$ \\
\hline $\begin{array}{l}\text { Agricultural } \\
\text { production }\end{array}$ & Rain-fed cropland & 519.32 & 32.17 \\
$\begin{array}{c}\text { Commercial } \\
\text { purpose }\end{array}$ & Fallow cropland & 36.56 & 2.26 \\
Ecosystem & Pasture grassland & 221.81 & 13.74 \\
services purpose & Woodland & 95.03 & 5.89 \\
& Shrubland & 104.18 & 6.45 \\
& Sparse natural & 582.66 & 36.09 \\
Orassland & 54.80 & 3.39 \\
Tothers & Residential land & 1614.36 & 100 \\
\hline
\end{tabular}


Data Processing and Methods

Digital topographic data was used to derive slopes and aspects data that were used for land use suitability evaluation. ALOS images were used for delineating current land use (Huang and others 2010). Face-to-face interviews identified the key issues faced by local farmers and their daily needs.

\section{Land Use Suitability Evaluation}

Land use suitability assessment offers a basis for sustainable land use planning and ecosystem management. In general, land use suitability is affected by landscape features, soil types and climate factors. However, given a very small study site, the spatial difference of land use suitability was predominantly influenced by landscape and soil factors because of the small variation of precipitation and dramatic change of evapotranspiration related to landscape position (McVicar and others 2007b). We use landforms, soil, slope and aspect to build a deterministic model for land use suitability evaluation (Table 2).

In the ecosystem service valuation model, the ecosystem service on soil and water conservation was specifically examined because the other services (e.g., carbon sequestration, water supply, timber production and recreation) were relatively less important. The minimum area to be used for maintaining ecosystem functions was identified in terms of soil and water conservation. The economic value of ecosystem service was evaluated by comparing the following three land use scenarios.

(I) CLU (Current Land Use): The current land use pattern in the catchment is maintained. In this case, the economic benefits and ecosystem services are examined based on the productivity of all land use type and total inputs in watershed scale. Because the agricultural management varies from farm to farm, thus the total agricultural input in general in the watershed was considered.
(II) GOLU (Grain-production oriented land use): All areas (including the steep land) in the watershed are simulated to be used for agricultural production. This means that land suitable to ecosystem services will be converted into cropland.

(III) PSLU (Potential sustainable land use): Steep slope land (i.e., $>25^{\circ}$ ) will be used for ecosystem service purposes, and cropland $\left(<15^{\circ}\right)$ or commercial woodland $\left(15^{\circ}-25^{\circ}\right)$ that have gentle slopes where terraces are built for soil erosion control.

The economic productivity of the three land use scenarios can be calculated as:

$E P_{i}=A C_{i} \times U Y_{i} \times M P_{i}$

where, $E P_{i}$ is the economic productivity obtained from the $i$ th crop plantation (or other on-farm products) (\$), $A C_{i}$ is the planted area of $i$ th crop (ha), $U Y_{i}$ is the unit yield of $i$ th crop $(\mathrm{kg} / \mathrm{ha})$, and $M P_{i}$ is the market price of $i$ th crop plantation $(\$ / \mathrm{kg})$.

\section{Ecosystem Service Assessment}

In the loess hilly area, planting shrubs in the steep slope may function as buffer to protect the terrace cropland from destruction due to soil erosion (Fu and Chen 2000; Wang and others 2000). The terrace croplands can be used for 30 years in the case that soil erosion in both steep hill-slopes and gully-slopes is controlled properly (Jiao and Wang 1999; Liu and Zhu 1996). However, the lifetime of terrace croplands is about ten rather than 30 years if serious soil erosion does happen. Therefore, the economic value of shrub plantation in the steep slope can be estimated by comparing the difference of economic productivity and loss for the above scenarios. Hereby, a period of 30 years was examined. In GOLU, the total economic productivity obtained from on-farm work is calculated as the economic earning from the crop plantation minus the cost of terrace-building of its dysfunction due to soil erosion. In general, the unit yield of

Table 2 Land use suitability evaluation model

\begin{tabular}{|c|c|c|c|c|}
\hline \multirow[t]{2}{*}{ Factors } & \multicolumn{4}{|c|}{ Purpose of land use } \\
\hline & Land for $\mathrm{e}$ & ervices purposes & $\begin{array}{l}\text { Land for commercial purpose, } \\
\text { e.g., orchard/pasture }\end{array}$ & Land for agricultural production \\
\hline Landforms & \multicolumn{2}{|c|}{ Gully, gully slope, steep hill-slope } & Mod-steep hill slope & Mod-steep to gentle hill-slope \\
\hline Soil & Sierozem & Loessial soil & Loessial soil & Loessial soil \\
\hline Slope degree $\left({ }^{\circ}\right)^{\mathrm{a}}$ & All & $>25$ & $15-25$ & $<15$ \\
\hline Slope aspect $\left({ }^{\circ}\right)^{\mathrm{b}}$ & All & All & $90-270$ & $90-270$ \\
\hline
\end{tabular}

a The degree is that from horizontal

b The degree is that (clockwise) from north 
the terrace cropland is 3 times of that of steep slope cropland (Ma 2003; Chen and others 2003). Thus the crop yield of the terrace cropland is about 3 times of steep slope cropland at the beginning and tends to a same value of slope cropland at the year of terrace dysfunction, although Wei and others (1998) reported that the benefits of the agroforestry system in terraced slopes is more than four times that of the slope cropland. Therefore, the total economic productivity of GOLU is estimated by

$$
\begin{aligned}
E P_{i}= & \sum_{i=1}^{m} \sum_{j=1}^{10} 3 \times A C_{i} \times U Y_{i} \times M P_{i} \\
& \times(1-r)^{j-1}-3 \times U C_{t} \times \sum_{i=1}^{m} A C_{i}
\end{aligned}
$$

where, $r$ is the decrease rate of crop yield each year due to the dysfunction of terrace, $j$ is the $j$ th year after terracebuilding, $m$ is the number of crops, $U C_{t}$ is unit cost of terrace building which is to be built three times in the period of 30 years. We assume that crop yield from terrace is maximum just after terrace construction and decreases linearly through time to a minimum value (defined as the crop yield from slope cropland) when the terrace is thoroughly dysfunctioned (i.e., 10 years).

The total economic productivity of PSLU scenario is calculated as

$$
\begin{aligned}
E P_{i}= & \sum_{j=1}^{30} \sum_{i=1}^{m} A C_{i} \times U Y_{i} \times M P_{i} \\
& \times(1-a)^{j-1}-U C_{t} \times \sum_{i=1}^{m} A C_{i}
\end{aligned}
$$

here, the $a$ is the decrease rate of the $i$ th crop yield due to soil erosion with terrace dysfunction, and the other parameters have the same meaning to Eq. 2. In this case, we assume that the yield of the terrace cropland linearly tends to the same value of steep slope cropland 30 year after the terrace is constructed (i.e., a terrace lasts 30 years before becoming dysfunctional due to the stabilization of planting shrubs), and $a$ is a constant of yield decline.

\section{Public Participation and Analysis}

An interview of the agricultural activities undertaken by local farmers was conducted in the summer of 2009. The following data was obtained for statistical analysis: (i) population, (ii) labor, (iii) education, (iv) cropland plantation area, (v) plantation type, (vi) animal breeding, (vii) energy source and utilization, (viii) income from onfarm and off-farm work, (ix) daily expenditure, (x) agricultural input and output, (xi) environmental awareness. Based on interview, the total annual expenditure of local farmers is obtained.

\section{Results}

Current Land Use Pattern and Land Use Suitability

Sparse natural grassland and rain-fed cropland are the predominant land use types, followed by pasture grassland, shrubland, woodland, residential land and follow cropland (Table 1). All the land use types are distributed with respect to aspect, but irregularly according to slope (Figs. 1, 2). Since the semi-sunny aspect is the largest group in the catchment, each land use type is located predominantly in these areas, which is about $40-50 \%$ of the total study area. Rain-fed cropland and residential land are mainly distributed in the slopes between 8 and $25^{\circ}$. However, the other land use types, such as fallow cropland, pasture grassland, woodland, shrubland, sparse natural grassland dominated slopes of $15-25^{\circ}$, then $8-15^{\circ}$ and $>25^{\circ}$. As expected, the land use types with more human footprint are generally located on gentle slopes, while the land use types less affected by human are mostly situated on steep slopes. This implies that the human effect is decreasing with an increasing in slope.

The suitable area for agricultural production is about 461 ha or $29 \%$, and the suitable area for commercial purpose accounts for approximately $30 \%$, i.e. 482.2 ha (Fig. 3). In contrast, as much as $41 \%$ of the study area, i.e. 670.7 ha, is unsuitable for both agricultural use and commercial purpose. These areas should be used for ecosystem services including soil and water conservation. However, more than $37.8 \%$ of the study area is currently used for agricultural production, and only about $14.0 \%$ of the land is used for pasture grassland (Table 1; Fig. 3). Although a large amount of land was used for land uses with less human disturbance, the largest group is sparse natural grassland which gives less ecosystem services value than the woodland/shrubland (Chen and others 2007b, 2010). Thus, opportunities exist to improve the current land use pattern for ecosystem health and management.

\section{Economic Productivity of Current Land Use and Two} Land Use Scenarios

Annual economic productivity of farm work is calculated by considering the yield and market price of each agricultural product, and the cost of yearly terrace maintenance (Table 3). The total annual economic productivity of the entire catchment is $\$ 827,614$, and the annual income per capita is about $\$ 516$. These results are based on the assumption that the current terrace cropland can be used for 30 years.

The economic productivity of two land use scenarios of deforestation and afforestation are provided in Tables 4 and 5, respectively. GOLU assumes that all the land on 
Fig. 1 The relationship between current land use and aspect (a)

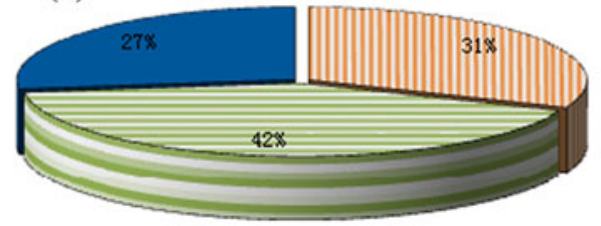

(c) Fallow Cropland vs Aspect
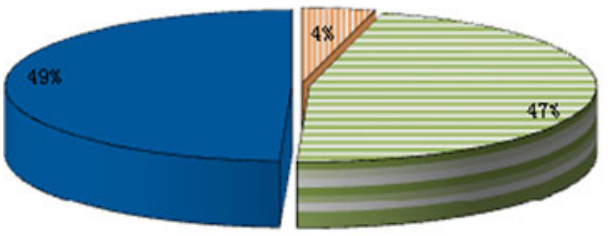

(e) Woodland vs Aspect

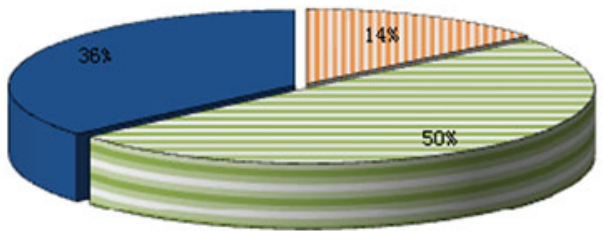

(g) Sparse Natural Grassland vs Aspect

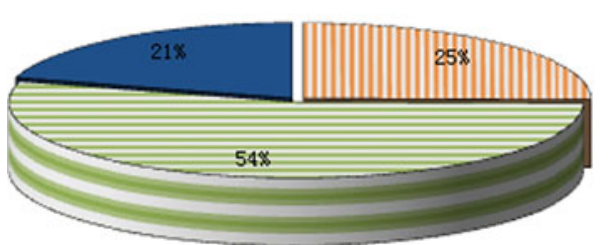

(b)

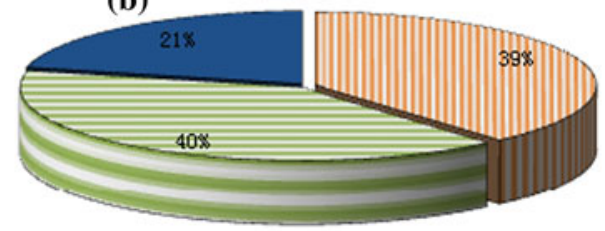

(d) Pasture Grassland vs Aspect

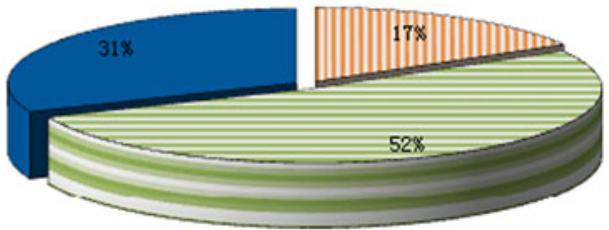

(f) Shrubland vs Aspect



Key:

$\square$ Sunny slope

日 Semi-sunny slope

Shady slope steep slopes is used for agricultural production, as was common in the 1970s. PSLU assumes the slopes with a gradient $>25^{\circ}$ will be afforested. Even if no much difference on the economic productivity exists between these two scenarios in the short-term, the PSLU scenario has a better economic productivity than GOLU in the long-term. The results imply that ecosystem services from converting the slope cropland into woodland/shrubland in the steep slopes awards $\$ 66,546$ annually. We also found that the plausible future economic scenario to change slope cropland into woodland/orchard/pasture grassland may result in economic losses initially (i.e., the first 5 years). It is necessary to refine this scenario to safeguard both ecological benefits and economic benefits in the longer term (Tables 4, 5). In addition, PSLU promises a more favorable landscape in contrast to the landscape that farmers faced in the 1970s and might face in GOLU as a result of severe soil erosion.

In terms of annual economic productivity, PSLU is more optimal, then GOLU, and the current land use is the lest optimal in the long-term. The lower economic productivity of current land use compared to PSLU is largely due to the reduction of orchard, and the conversion of much land to sparse natural grassland. Compared with GOLU, there is less agricultural production in current land use. However, unlike PSLU, GOLU may result in serious soil erosion and poor ecosystem services. Although far from being perfect, this comparison may help make improved decisions in regulating land use structure and investing in ecosystem services.

\section{Annual Expenditure of Local Farmer for Daily Life}

Table 6 indicates the total economic income and daily expenditure of the local farmers based on interview data. Some difference exists between the interview results and calculation results (Tables 3, 6). This is because the income from on-farm work is calculated at best cases. In fact, the crop yield may not reach the average value in the years, and not all the planted crop produce outcome. However, comparing the annual economic income and annual consumption of the study area, we found that the production from on-farm work can not sustain human needs (Table 6). This implies that on-farm work only is not economically viable. Based on the interview with local farmers, we also found that off-farm income played a pivotal role in improving their quality of life, and the 
Fig. 2 The relationship between current land use and slope (a) Rain-fed Cropland vs Slope

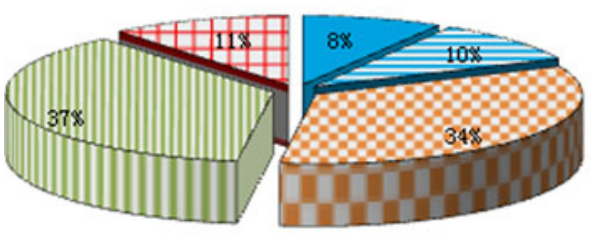

(c) Fallow Croplandvs Slope

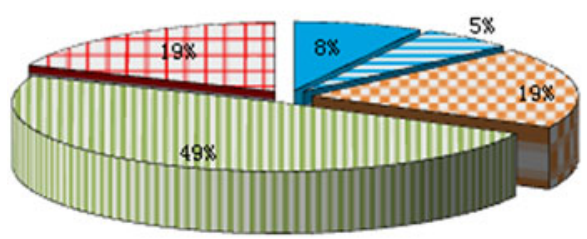

(e) Woodlandvs Slope



(g) Sparse Natural Grassland vs Slope

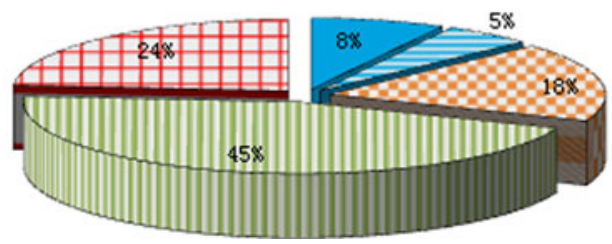

(b) Residential Landvs Slope

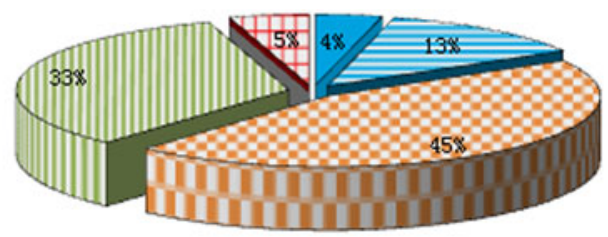

(d) Passture Grassland vs Slope



(f) Shrub Land vs Slope

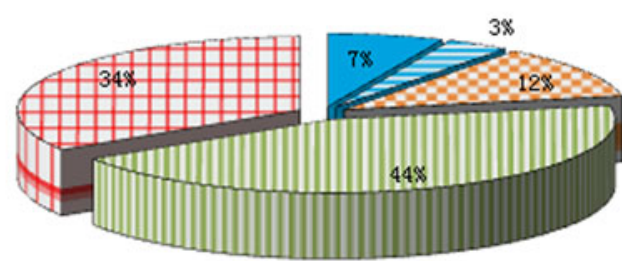

Key:

$\square 0^{\circ}-3^{\circ} \square 3^{\circ}-8^{\circ} \square 8^{\circ}-15^{\circ}$

ㅁ $15^{\circ}-25^{\circ} \square>25^{\circ}$

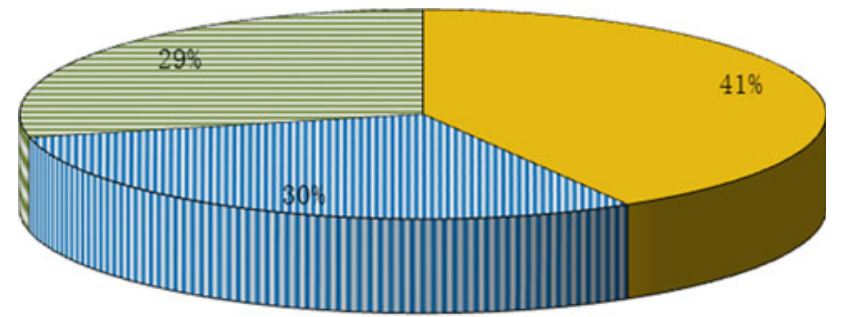

$\square$ Land for ecosystem services 四 Land for commercial purpose

目 Land for agricultural purpose

Fig. 3 Land use suitability in the study area

income from off-farm work contributed positively to the total income per capita (Fig. 4d). The income from the other sources, for example grain production, pasture grassland, and husbandry has a negative relationship with the income per capita (Fig. 4b, c), or unclear relationship
(Fig. 4a). This means that external assistance (export of labor services, state subsistence) was required to reach long-term economic development.

\section{Discussion}

Role of Soil Erosion Control in Sustainable Land Use Planning

A large part of the study watershed, such as areas with slopes exceeding $25^{\circ}$ and the sierozem area, was unsuitable for agricultural production. Although slope croplands may produce some productivity in the short-term, the transformation of these areas from crop to ecosystem services use would give better outcome in the long-term for the whole watershed (Table 5). The loess plateau has been suffering from soil erosion for a long time due to human activities. In 
Table 3 The economic productivity of current land use (2009)

\begin{tabular}{|c|c|c|c|c|c|}
\hline \multicolumn{2}{|l|}{ Land use type } & \multirow{2}{*}{$\begin{array}{l}\text { Area (ha) } \\
519.34\end{array}$} & \multirow{2}{*}{$\begin{array}{l}\text { Unit yield (kg/ha) } \\
\text { 13,953/once }\end{array}$} & \multirow{2}{*}{$\begin{array}{l}\text { Unit price }(\$ / \mathrm{kg})^{\mathrm{a}} \\
7246,605 / 30 \mathrm{a}\end{array}$} & \multirow{2}{*}{$\begin{array}{l}\text { Annual total } \\
\text { economic income }(\$) \\
241,553 / \text { each year }\end{array}$} \\
\hline Terrace building & & & & & \\
\hline \multirow[t]{6}{*}{ Agricultural production } & Total area & 519.34 & & & \\
\hline & Residential land & 54.8 & - & - & - \\
\hline & Potato & 209.04 & 22,500 & 0.093 & 437,532 \\
\hline & Maize & 69.68 & 9,000 & 0.248 & 155,567 \\
\hline & Wheat & 69.68 & 2,250 & 0.310 & 48,615 \\
\hline & Others & 116.13 & 1,500 & 0.558 & 97,229 \\
\hline Commercial purpose & Pastureland & 221.87 & 12,000 & 0.124 & 330,225 \\
\hline \multirow[t]{3}{*}{ Ecosystem service } & Woodland & 95.03 & & & - \\
\hline & Shrubland & 304.02 & 22,500 & & - \\
\hline & Sparse natural grassland & 101.34 & 9,000 & - & - \\
\hline \multicolumn{5}{|c|}{ Annual total income from on-farm work $(\$)$} & 1069,167 \\
\hline \multicolumn{5}{|c|}{ Annual net income by subtracting the cost of terrace maintenance $(\$)$} & 827,614 \\
\hline \multicolumn{5}{|c|}{ Annual income per capita $(\$)^{\mathrm{b}}$} & 536 \\
\hline
\end{tabular}

a $\$ 100=¥ 645$ (Chinese currency unit)

b The population used in the study area is 1,545

Table 4 The economic productivity of the scenario of grain-production oriented land use (GOLU)

\begin{tabular}{|c|c|c|c|c|c|c|}
\hline & & Area (ha) & $\begin{array}{l}\text { Unit yield } \\
(\mathrm{kg} / \mathrm{ha})\end{array}$ & $\begin{array}{l}\text { Unit price } \\
(\$ / \mathrm{kg})^{\mathrm{a}}\end{array}$ & $\begin{array}{l}\text { Total income in } \\
\text { the first year }(\$)\end{array}$ & $\begin{array}{l}\text { Total income } \\
\text { in } 30 \text { years }(\$)\end{array}$ \\
\hline \multicolumn{2}{|c|}{ Terrace building in the slope less than $15^{\circ}$} & 461.38 & 3 times & $\$ 13,953 /$ ha & $6437,635 /$ once & $19,312,905$ \\
\hline \multirow[t]{6}{*}{ Agricultural production } & Total area & 461.38 & & & & \\
\hline & Residential land & 54.80 & - & - & - & \\
\hline & Potato & 182.96 & 22,500 & 0.093 & 382,945 & 7045,507 \\
\hline & Maize & 60.99 & 9,000 & 0.248 & 136,158 & 2505,069 \\
\hline & Wheat & 60.99 & 2,250 & 0.310 & 42,550 & 782,834 \\
\hline & Others & 101.65 & 1,500 & 0.558 & 85,099 & 1565,668 \\
\hline \multirow[t]{3}{*}{ Commercial purpose } & Total area & 477.37 & & & & \\
\hline & Orchard & 159.12 & 15,000 & 0.310 & 740,103 & 13465,847 \\
\hline & Pastureland & 318.24 & 12,000 & 0.124 & 473,666 & 8618,142 \\
\hline \multirow[t]{5}{*}{ Ecosystem services } & Total area & 675.61 & & & & \\
\hline & Potato & 304.02 & 22,500 & 0.093 & 212,110 & 6363,301 \\
\hline & Maize & 101.34 & 9,000 & 0.248 & 75,417 & 2262,507 \\
\hline & Wheat & 101.34 & 2,250 & 0.310 & 23,568 & 707,034 \\
\hline & Others & 168.90 & 1,500 & 0.558 & 47,136 & 1414,067 \\
\hline \multicolumn{5}{|c|}{ Total income from on-farm work $(\$)$} & 2218,751 & 44729,977 \\
\hline \multicolumn{5}{|c|}{ Total net economic income from on-farm work in the 30 years $(\$)^{\mathrm{b}}$} & 25417,071 & \\
\hline \multicolumn{5}{|c|}{ Annual net economic income from on-farm work (\$) } & 847,236 & \\
\hline \multicolumn{5}{|c|}{ Annual economic income per capita from on-farm work $(\$)^{\mathrm{c}}$} & 548 & \\
\hline
\end{tabular}

a $\$ 100=¥ 645$ (Chinese currency unit)

b The total economic income in the 30 years is result of total income from on-farm work subtracts the cost of terrace building

c The population in the study area used is 1,545

the past decades, much effort has been spent to control soil erosion by improving vegetation coverage and ecosystem function (e.g., Chen and others 2007a; Tian 2010; Wang and others 2010; Zhang and Liu 2007). Unfortunately, how to define sustainable land use pattern at a watershed scale is still not clear in the loess hilly area. Our study suggests that 
Table 5 The economic productivity of the scenario of potential sustainable land use (PSLU)

\begin{tabular}{|c|c|c|c|c|c|c|}
\hline & & Area (ha) & $\begin{array}{l}\text { Unit yield } \\
(\mathrm{kg} / \mathrm{ha})\end{array}$ & $\begin{array}{l}\text { Unit price } \\
(\$ / \mathrm{kg})^{\mathrm{a}}\end{array}$ & $\begin{array}{l}\text { Total income } \\
\text { the first year }(\$)\end{array}$ & $\begin{array}{l}\text { Total income } \\
\text { in } 30 \text { years }(\$)\end{array}$ \\
\hline \multicolumn{2}{|c|}{ Terrace building in the slope less than $15^{\circ}$} & 461.38 & 1 times & $\$ 13,953 /$ ha & - & 64,37918 \\
\hline \multirow[t]{6}{*}{ Agricultural production } & Total area & 461.38 & & & & \\
\hline & Residential land & 54.80 & - & - & - & \\
\hline & Potato & 182.96 & 22,500 & 0.093 & 382,945 & 696,7527 \\
\hline & Maize & 60.99 & 9,000 & 0.248 & 136,158 & 24,77343 \\
\hline & Wheat & 60.99 & 2,250 & 0.310 & 42,550 & 774169.6 \\
\hline & Others & 101.65 & 1,500 & 0.558 & 85,099 & 1548,339 \\
\hline \multirow[t]{3}{*}{ Commercial purpose } & Total area & 477.37 & & & - & - \\
\hline & Orchard & 159.12 & 15,000 & 0.310 & 740,103 & 13465,847 \\
\hline & Pastureland & 318.24 & 12,000 & 0.124 & 473,666 & 8618,142 \\
\hline \multirow[t]{3}{*}{ Ecosystem services } & Total area & 675.61 & & & & \\
\hline & Woodland & 225.20322 & - & - & - & - \\
\hline & Natural grassland & 450.40644 & - & - & - & - \\
\hline \multicolumn{5}{|c|}{ Total income from on-farm work $(\$)$} & 1860,521 & 33851,368 \\
\hline \multicolumn{5}{|c|}{ Total net economic income from on-farm work 30 years $(\$)^{\mathrm{b}}$} & 27413,450 & \\
\hline \multicolumn{5}{|c|}{ Annual net economic income from on-farm work (\$) } & 913,782 & \\
\hline \multicolumn{5}{|c|}{ Annual economic income per capita from on-farm work $(\$)^{\mathrm{c}}$} & 591 & \\
\hline
\end{tabular}

${ }^{\mathrm{a}} \$ 100=¥ 645$ (Chinese currency unit)

b The total economic income in the 30 years is result of total income from on-farm work subtracts the cost of terrace building

c The population in the study area used is 1,545

Table 6 Comparison on income and expenditure of local farmers based on interview data

\begin{tabular}{|c|c|c|c|c|c|c|c|}
\hline \multicolumn{4}{|l|}{ Income } & \multicolumn{4}{|l|}{ Expenditure } \\
\hline Items & In total $(\$)^{\mathrm{a}}$ & Per capita (\$) & Percent $(\%)$ & & In total $(\$)$ & Per capita $(\$)$ & Percent $(\%)$ \\
\hline Crop plantation & 117,778 & 229.1 & 37.40 & Grain consumption & 75,952 & 150.7 & 25.17 \\
\hline Orchard & 1,886 & 3.7 & 0.60 & Agricultural input & 30,212 & 59.9 & 10.01 \\
\hline Pasture grassland & 7,458 & 14.5 & 2.37 & Dining spices & 19,499 & 38.7 & 6.46 \\
\hline Animal breeding & 8,576 & 16.7 & 2.72 & Education & 20,479 & 40.6 & 6.79 \\
\hline Labor export & 117,039 & 227.7 & 37.16 & Social and daily life & 122,004 & 242.1 & 40.43 \\
\hline Manufacture & 2,583 & 5.0 & 0.82 & Life improvement & 33,652 & 66.8 & 11.15 \\
\hline State subsistence & 59,633 & 116.0 & 18.93 & & & & \\
\hline In total & 314,953 & 612.8 & 100 & In total & 301,797 & 598.8 & 100 \\
\hline
\end{tabular}

${ }^{a} \$ 100=¥ 645$ (Chinese currency unit). The households interviewed in this study are 129, and the people interviewed are 514

a suitable land use pattern should have a land distribution of $40 \%$ for ecosystem services use, $30 \%$ for orchard/pasture grassland, and $30 \%$ for agricultural production.

In order to realize sustainable land use in the loess hilly area, the following measures should be considered. First, soil erosion risk due to human activities must be evaluated. Previous studies indicate that the slope cropland produces much more soil loss than pasture grassland, shrubland and woodland (e.g., Huang and others 2006; Wei and others 2007). Magnitude and spatial distribution of areas sensitive to soil erosion needs to be identified for a specific region. In land use planning, these areas are to be designated as area for ecosystem services (McVicar and others 2010). Second, the trade-off between economic loss due to soil erosion and economic benefits obtained from crop plantation needs to be examined in the long-term rather than the short term. In our study, GOLU of planting crops in the steep slopes may give a higher annual economic productivity at the beginning than PSLU. However, the economic earning of reclaiming the steep slopes is economically 
(a) per capita vs grain production/total income

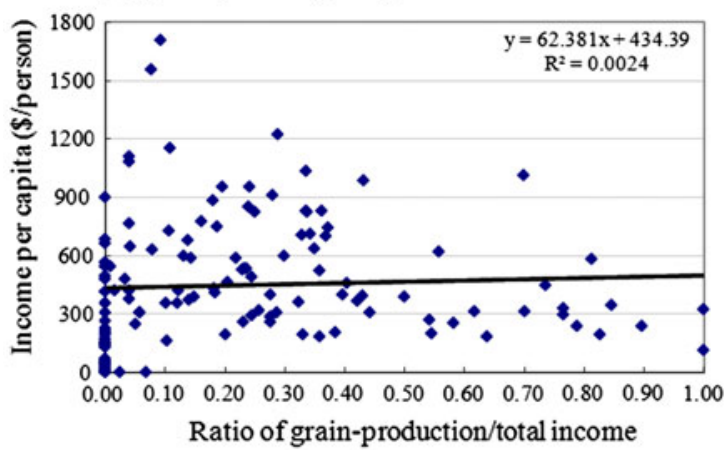

(c) per capita vs husbandry/total income



Fig. 4 The relationship between income sources and per capita income unsustainable in the long-term when the cost of terrace construction and maintenance is taken into account. This means that ecosystem management by integrating ecosystem services is necessary. However, it is challenging for both local farmers and governments to make decisions on sustainable land use planning by integrating ecosystem services at the watershed scale. Third, public participation in soil erosion control and watershed ecosystem management is to be fostered. Integrated watershed management for soil and water conservation has proven to be a useful means to reduce soil erosion and to reinforce ecosystem functions in the loess plateau (Chen and others 2007a; Mu and others 2007). However, it was not widely implemented in the loess plateau since it requires large financial and human resources. Since integrated watershed management for soil and water conservation is ultimately borne by local farmers, their cooperation will be important. However, most farmers consider the government to be in full charge of soil and water conservation. This means that looking for a feasible way to encourage public participation in integrated watershed ecosystem management is an important task in the loess plateau. We suggest that subsistence be given to the local farmers in proportion to their direct involvement in the integrated ecosystem management. This is much better than the direct compensation without crosscompliance, as is currently implemented in China (Liu and Yao 2010). (b) per capita vs agoforestry production/total income

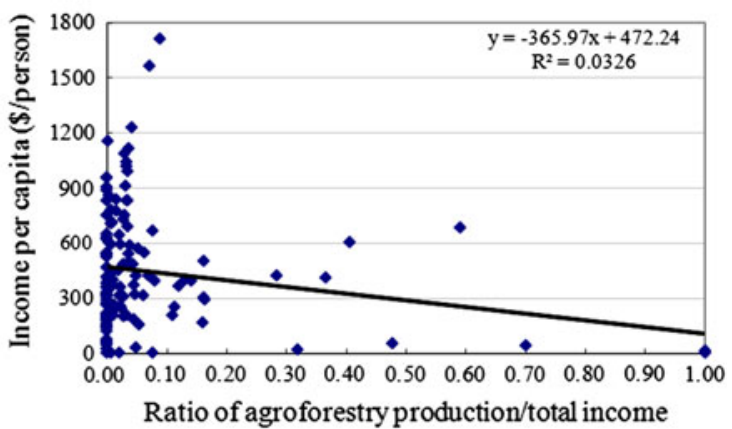

(d) per capita vs off-farmland/total income

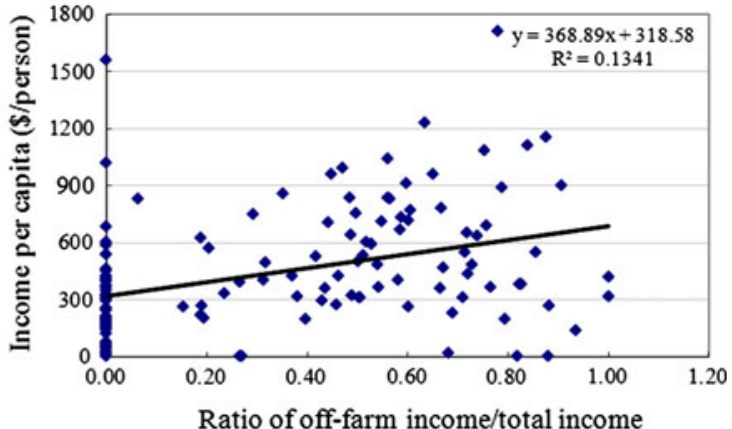

Role of Ecosystem Services in Ecosystem Management at Watershed Scale

Integrating ecosystem services in watershed management is crucial for sustainable development. In general, ecosystem services can be defined as the benefits that humans obtain from nature (Costanza and Daly 1992; Daly and Farley 2003; Daily 1997; de Groot and others 2002; Ekins and others 2003). They are classified into four categories: (I) provisioning services; (II) regulatory services; (III) cultural services; and (IV) supporting services (MEA 2005). This concept offers a general framework for ecosystem services assessment, however, the approach to estimate economic value of ecosystem services varies according to the regions and the ecosystems. Although potential trade-offs between carbon sequestration and other ecosystem services are important in the regions with scarce water resource (Chisholm 2010), only the ecosystem services of soil and water conservation are considered in our study. This is because the flow of services from ecosystems requires that they function as a whole system: structure, composition and diversity of the ecosystem are important components of natural capital that cannot be separated. Because of the scarce water resource in the semi-arid loess hilly area, vegetation growth is slow and ecosystems are vulnerable (e.g., McVicar and others 2007a, 2010). The other ecosystem services such as firewood provisioning and 
recreation may not enact in practice if the services on soil and water conservation is kept except for biodiversity conservation which is, however, not as important as soil and water conservation in the loess hilly area.

The reduction of genetic, stand and landscape biodiversity is usually intentional when land is used by human to enhance the productivity of a particular ecosystem service. Such phenomenon occurred in the loess plateau in the 1970s when, driven by population explosion, a large amount of slope land was converted to agricultural production. Consequently, the local economy was not improved and the ecosystem services were widely degraded. Acknowledging ecosystems and convincing land use stakeholders of their importance is often not considered by local governments, because it is difficult to evaluate them quantitatively. A strong demand on more ecosystem-service research and practice exists in the undeveloped regions of China, largely because widespread poverty implies that any expenditure on environmental programs from state government must be justified in economic and social terms. Quantification of ecosystems providing services is a prerequisite for economic valuation, but unfortunately this has systematically been done in ecology only until recently (Chisholm 2010). In watershed ecosystem management, key question is how to incorporate the ecosystem services into ecosystem management for sustainable development of a region. In our study, scenario analysis was employed and the trade-off between scenarios was compared in the long-term. We found that integrated watershed ecosystem management by implementation of ecosystem services in land use planning is promising. However, it is often ignored in the decision on land use planning in China.

Sustainable Development Thorough Integrated Ecosystem Management at a Watershed Scale

Our results show that it is impossible to realize sustainable land use or sustainable development in the semi-arid loess hilly area by using the local resource only (Table 6). Thereby, adopting an integrated ecosystem management at the watershed scale is of special importance. Our study recommend following measures for the sustainability in land use and ecosystem management.

(1) Adjustment of the land use pattern is required in line with the need to transform the labor-intensive farming system to a labor-saving one. Based on the results of scenario analysis, the current land use pattern gives rise to the lowest economic productivity compared with the other two scenarios (Tables 3, 4, 5), and the daily demand of the local farmers can't be met by onfarm work. It was also indicated that the income from off-farm work contributes largely to the total income of household (Table 6). Thus, finding a labor-saving farming system may help improve income-generation and the sustainability of likelihood since more income may be obtained by extricating the local farmers from on-farm work. We also found that under the three land use scenarios, afforestation is associated with large future economic gains, suggesting a need for greater future use of more land for ecosystem services and commercial purpose.

(2) Diversification of agricultural income and low risk on agricultural production is required for sustainable development. Private landholders, motivated primarily by profit, might choose to manage their lands for a single ecosystem service. However, a region in which the economy depends entirely on one extractive industry is poorly buffered against market fluctuations (Chapin and others 2009). In general, the risks of unfavorable land use adjustment outcomes can be minimized through careful planning by multiple user groups to assess the risks of good and bad outcomes; transparent navigation of the transformation process; and fostering resilience of those outcomes that meet broad societal goals (Nettle and Romaine 2000).

(3) The public participation in integrated watershed ecosystem management should be encouraged in the semiarid loess hilly area. There is a growing awareness that successful erosion control and sustainable land use requires consideration of the local farmer's needs and willingness (Fagerström and others 2003). It is hard to control soil erosion without farmers' participation and cooperation. However, environmental awareness of local farmers in the loess plateau is currently poor. For most farmers, grain production is considered much more important than environmental conservation (Chen and others 2007a; $\mathrm{Hu}$ and others 2006). In order to ensure effectiveness and sustainability of soil and water conservation, education on environmental conservation to local farmers should be reinforced. Above all, the local people should be encouraged to participate in sustainable land use planning and vegetation restoration. Because sometimes local people understand the nature better than scientists and politicians, their solution to soil erosion control and vegetation restoration is pertinent (Fagerström and others 2003; Stolte and others 2005). Usually, nature is exploited by the local people with little thinking about its environmental effects. It is urgent to tell the people that to protect nature may help improving their own life as the PSLU shows. Third, financial means are necessary to encourage local people to participate in environmental conservation, and in integrated watershed ecosystem management. Although some compensation is given to the local farmers for their converting the slope cropland into the other uses (Zhang and Liu 2007; Wang and others 2010), at present little financial 
encouragement is given as payment for the other environmental protection actions (Chen and others 2007a).

\section{Conclusion}

Ecosystem management that can address trans-boundary, interdisciplinary, and multi-party issues from an ecosystem perspective should be evaluated in the long-term by incorporating public opinion, preferences, and the ecosystem service values. Although ecosystem management has been proposed for many years and promoted in many regions, it is still conceptual in most developing nations. Integrated ecosystem management is difficult to understand for stakeholders such as local officials and local farmers, and in many cases scientists face problems in developing a workable scheme for a specific region. However, integrated ecosystem management is extremely important for sustainable development because of its holistic and sustainability approach.

Scenario analysis is a useful approach in the integrated ecosystem management. In our study, it was employed to compare the economic productivity of three land use scenarios. The trade-off between them becomes visible when factors such as land use suitability, economic earning, and ecosystem services were combined in the analysis. Our study suggests that ecosystem services should be examined in the long-term rather than in the short-term when ecosystem management scheme is planned. It was found that the Grain-production Oriented Land Use has a better economic benefit than Potential Sustainable Land Use in the short-term, but not in the long-term. This implies that integrated ecosystem management for sustainable development requires viewing nature and sustainability in a future perspective. However, it is challenging to implement such principles in a resource-poor region, such as the semiarid loess hilly area.

Development of integrated ecosystem management for sustainable development takes time in the semi-arid loess hilly area. We found that both the current and the potential sustainable land use are not able to afford the daily needs of the local farmers based on on-farm work only. Thus, external financial assistance is necessary. There are two ways to proceed. The first is compensation directly from the state government. We suggest that it should be given to the local farmers based on their involvement in ecosystem management rather than directly providing them with cash. The second is increasing off-farm employment for local farmers because it is the major contribution of the total income. To reach this goal, transformation from the current land use system to a new one that may partially relieve the local farmers from farming only is needed. In light of these issues, the loess plateau region has much to do to achieve the desired sustainable development.

Acknowledgments Financial support for this research comes from the National Natural Science Foundation of China (40925003; 41071122) and the Chinese Academy of Sciences (kzcx2-yw-421). The authors would like to thank Dr. Ge Sun at United States Forest Service for his help on editing an early draft. The authors are grateful of the anonymous reviewers for their valuable suggestions in improving the manuscript.

\section{References}

Balvanera P, Pfisterer AB, Buchmann N, He JS, Nakashizuka T, Raffaelli D, Schmid B (2006) Quantifying the evidence for biodiversity effects on ecosystem functioning and services. Ecology Letters 9:1146-1156

Berry J, Brewer GD, Gordon JC, Patton DR (1998) Closing the gap between ecosystem management and ecosystem research. Policy Sciences 31:55-80

Cervantes O, Espejel I, Arellano E, Delhumeau S (2008) Users' perception as a tool to improve urban beach planning and management. Environmental Management 42:249-264

Chapin III FS, Carpenter SR, Kofinas GP, Folke C, Abel N, Clark WC, Olsson P, Smith DMS, Walker B, Young OR, Berkes F, Biggs R, Grove JM, Naylor RL, Pinkerton E, Steffen W, Swanson FJ (2009) Ecosystem stewardship: sustainability strategies for a rapidly changing planet. Trends in Ecology and Evolution 25:241-149

Chen QB, Wang KQ, Qi S, Sun LD (2003) Soil and water erosion in its relation to slope field productivity in hilly gully areas of the loess plateau. Acta Ecologia Sinica 23:1463-1469 (In Chinese with an English abstract)

Chen LD, Wei W, Fu BJ, Lü YH (2007a) Soil and water conservation on the loess plateau in China: review and perspective. Progress in Physical Geography 31:389-403

Chen LD, Huang ZL, Gong J, Fu BJ, Huang YL (2007b) The effect of land cover/vegetation on soil water dynamic in the hilly area of the loess plateau, China. Catena 70:200-208

Chen LD, Wang JP, Wei W, Fu BJ, Wu DP (2010) Effects of landscape restoration on soil water storage and water use in the loess plateau region, China. Forest Ecology and Management 259:1291-1298

Chisholm RA (2010) Trade-offs between ecosystem services: water and carbon in a biodiversity hotspot. Ecological Economics 69:1973-1987

Christensen NL, Bartuska AM, Brown JH, Carpenter S, Antonio CD, Francis R, Franklin JF, MacMahon JA, Noss RF, Parsons DJ, Peterson CH, Turner MG, Woodmansee RG (1996) The report of the Ecological Society of America committee on the scientific basis for ecosystem management. Ecological Application 6:665-691

Chuenpagdee RC, Liguori L, Preikshot D, Pauly D (2006) A public sentiment index for ecosystem management. Ecosystems 9:463-473

Costanza R, Daly HE (1992) Natural capital and sustainable development. Conservation Biology 6:37-46

Daily GC (1997) Nature's Services: Societal Dependence on Natural Ecosystems. Island Press, Washington D.C

Daly HE, Farley J (2003) Ecological Economics: Principles and Applications. Island Press, Washington D.C

de Groot R, Wilson MA, Boumans RMJ (2002) A typology for the classification, description and valuation of ecosystem functions, goods and services. Ecological Economics 41:393-408 
Ekins P, Folke C, de Groot R (2003) Identifying critical natural capital. Ecological Economics 44:159-163

Fagerström MH, Messing I, Wen ZM, Trouwborst KO, Xu MX, Zhang XP, Olsson C, Andersson C (2003) A participatory approach for integrated conservation planning in a small catchment in loess plateau, China: Part II. Analysis and findings. Catena 54:271-288

Fu BJ, Chen LD (2000) Agricultural landscape spatial pattern analysis in the semi-arid hill area of the loess plateau, China. Journal of Arid Environments 44:291-303

German L, Mansoor H, Alemu G, Mazengia W, Amede T, Stroud A (2006) Participatory integrated watershed management: evolution of concepts and methods in an ecoregional program of the eastern African highlands. Agricultural Systems 94:189-204

Heinimann HR (2010) A concept in adaptive ecosystem management - an engineering perspective. Forest Ecology and Management 259:848-856

Hu CX, Fu BJ, Chen LD, Gulinck H (2006) Farmer's attitudes towards Grain-for-Green program in the loess hilly area, China - a case study in two small catchments. International Journal of Sustainable Development and World Ecology 13:211-220

Huang ZL, Chen LD, Fu BJ, Lü YH, Huang YL, Gong J (2006) The relative efficiency of four representative cropland conversions in reducing water erosion: evidence from long-term plots in the loess hilly area, China. Land Degradation and Development 17:615-627

Huang WC, Chen YC, Cheng KS (2010) Comparing land cover patterns in Tokyo, Kyoto, and Taipei using ALOS multispectral images. Landscape and Urban Planning 97:132-145

Ingrahama MW, Foster SG (2008) The value of ecosystem services provided by the U.S. National Wildlife Refuge System in the contiguous US. Ecological Economics 67:608-618

Jiao JY, Wang WZ (1999) Quality and soil-water conservation effectiveness of level terrace on the loess plateau. Transactions of the CSAE 15(2):59-63 (In Chinese with an English abstract)

Knoche S, Lupi F (2007) Valuing deer hunting ecosystem services from farm landscapes. Ecological Economics 64:313-320

Kremen C (2005) Managing ecosystem services: What do we need to know about their ecology? Ecology Letters 8:468-479

Li TH, Li WK, Qian ZH (2008) Variations in ecosystem service value in response to land use changes in Shenzhen. Ecological Economics 69:1427-1435

Liu Z, Yao SB (2010) The empirical analysis on compensation standards and the length of compensation period of grain-toforest of loess plateau. Issues of Forestry Economics 28(1):86-89 (In Chinese with an English abstract)

Liu ZL, Zhu B (1996) Survey on terrace-farm construction in Zhuanglang County, Gansu Province. Soil and Water Conservation in China 1:6-7 (In Chinese)

Loorbach D (2007) Transition Management: New Mode of Governance for Sustainable Development, International Books

Ma RL (2003) Construction contents of terraced fields with slope and benefit analysis of Guyuan, Ningxia. Soil and Water Conservation in China 2:29-30 (In Chinese with an English abstract)

McVicar TR, Li LT, Van Niel TG, Zhang L, Li R, Yang QK, Zhang XP, Gao P (2007a) Developing a decision support tool for China's re-vegetation program: simulating regional impacts of afforestation on average annual stream flow in the loess plateau. Forest Ecology and Management 251:65-81

McVicar TR, Van Niel TG, Li LT, Hutchinson MF, Mu MX, Liu ZH (2007b) Spatially distributing monthly reference evapotranspiration and pan evaporation considering topographic influences. Journal of Hydrology 338:196-220
McVicar TR, Van Niel TG, Li LT, Wen ZM, Yang QK, Li R, Jiao F (2010) Parsimoniously modelling perennial vegetation suitability and identifying priority areas to support China's re-vegetation program in the loess plateau: matching model complexity to data availability. Forest Ecology and Management 259:1277-1290

MEA (2005) Ecosystems and Human Well-being: Synthesis. Island Press, Washington D.C

Mu XM, Zhang L, McVicar TR, Chille B, Gau (2007) Estimating the impact of conservation measures on stream-flow regime in catchments of the loess plateau, China. Hydrological Progress 21:2124-2134

Nettle D, Romaine S (2000) Vanishing Voices: The Extinction of the World's Languages. Oxford University Press, Oxford

Ostrom E (2007) A diagnostic approach for going beyond panaceas. Proceedings of the National Academy of Sciences of the United States of America 104:15181-15187

Pavlikakis GE, Tsihrintzis VA (2000) Ecosystem management: a review of a new concept and methodology. Water Resources Management 14:257-283

Prager K, Freese J (2009) Stakeholder involvement in agri-environmental policy making-learning from a local- and a state-level approach in Germany. Journal of Environmental Management 90:1154-1167

Stolte J, Ritsema CJ, Bouma J (2005) Developing interactive land use scenarios on the loess plateau in China, presenting risk analyses and economic impacts. Agriculture, Ecosystems \& Environment 105:387-399

Swintona SM, Lupia F, Robertson GP, Hamilton SK (2007) Ecosystem services and agriculture: cultivating agricultural ecosystems for diverse benefits. Ecological Economics 64:245-252

Tian JL (2010) Environmental Effects of Ecological-Construction in the loess plateau. China Meteorological Press, Beijing In Chinese

Tong CF, Feagin RA, Lu JJ, Zhang XF, Zhu XJ, Wang W, He WS (2007) Ecosystem service values and restoration in the urban Sanyang wetland of Wenzhou, China. Ecological Engineering 29:249-258

Turner RK, Daily GC (2008) The ecosystem service framework and natural capital conservation. Environmental and Resource Economics 39:25-35

Wang XL, Cai QG, Wang ZK, Sun GL (2000) The consolidating function and economic benefit analysis of the terrace hedgerows in the hilly loess region of northwest Hebei Province. Journal of Natural Resources 15:74-79 (In Chinese with an English abstract)

Wang DD, Wu PT, Zhao XN (2010) Benefit evaluation of conversion of cropland to forest project in the loess plateau. Journal of Northwest Forestry University 25(3):223-228 (In Chinese with an English abstract)

Wei TX, Zhu JZ, Zhu QK, Zhang ZZ (1998) Design of integral agroforestry and its benefits of soil and water conservation in loess steep slope land. Journal of Soil Erosion and Soil and Water Conservation 4(2):82-87 (In Chinese with an English abstract)

Wei W, Chen LD, Fu BJ, Huang ZL, Wu DP, Gui LD (2007) The effect of land uses and rainfall regimes on runoff and soil erosion in the semi-arid loess hilly area, China. Journal of Hydrology 335:247-258

Yaffee SL (1997) Three faces of ecosystem management. Conservation Biology 13:713-725

Zhang WH, Liu GB (2007) Review on vegetation restoration in the loess plateau. Scientia Silvae Sinicae 43(1):102-105 (In Chinese with an English abstract) 